\title{
Corrosion Behavior of Cupronickel Alloy in Simulated Seawater in the Presence of Sulfate-Reducing Bacteria
}

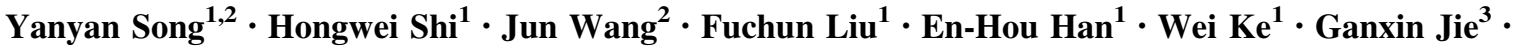 \\ Jun Wang ${ }^{3} \cdot$ Haijun Huang ${ }^{3}$
}

Received: 19 June 2017/Revised: 29 July 2017 / Published online: 14 October 2017

(c) The Chinese Society for Metals and Springer-Verlag GmbH Germany 2017

\begin{abstract}
The corrosion behavior of cupronickel alloy immersed in the simulated seawater in or without the presence of sulfate-reducing bacteria (SRB) was studied. The results of scanning electronic microscopy and electrochemical impedance spectra reveal that corrosion of the sample immersed in the simulated seawater with SRB was more serious than that immersed in the simulated seawater without SRB. The atomic force microscopy images show that after immersion for 15 days, the surface roughness of the sample in the simulated seawater with SRB was higher than that of the sample in the simulated seawater without SRB. The analysis of confocal laser scanning microscopy indicates that the average depth of the pits on the surface of the sample in the simulated seawater with SRB was almost twice deeper than that of the sample in the simulated seawater without SRB.
\end{abstract}

KEY WORDS: Microbiologically influenced corrosion; Sulfate-reducing bacteria; Cupronickel alloy; Confocal laser scanning microscopy; EIS

\section{Introduction}

In recent years, cupronickel alloys have been used in marine facilities, due to their excellent electrical conductivity, corrosion resistance, and easy processing [1]. Although cupronickel alloys show a good corrosion resistance, they

Available online at http://link.springer.com/journal/40195

Hongwei Shi

hwshi@imr.ac.cn

$\triangle$ Fuchun Liu

fcliu@imr.ac.cn

1 CAS Key Laboratory of Nuclear Materials and Safety Assessment, Institute of Metal Research, Chinese Academy of Sciences, Shenyang 110016, China

2 Department of Chemistry, Northeastern University, Shenyang 110004, China

3 State Key Laboratory of Environmental Adaptability for Industrial Products, National Electric Apparatus Research Institute Co., Ltd, Guangzhou 510633, China also suffer corrosion attack in corrosive species. There are some literatures reported on protective ability and corrosion behavior of cupronickel alloys. Badawy et al. found that the increase in $\mathrm{Ni}$ content improves the stability of the $\mathrm{Cu}-\mathrm{Ni}$ alloys. The surface film with high $\mathrm{Ni}$ content on $\mathrm{Cu}-\mathrm{Ni}$ alloys increases anticorrosion stability of the alloys [2]. The mechanism for the improvement of stability relies on the dissolution of $\mathrm{Ni}$ in cupronickel alloys, which is able to form a barrier layer of $\mathrm{Ni}(\mathrm{OH})_{2}$ or $\mathrm{NiO}$. The corrosion current density of polarization decreases as the $\mathrm{Ni}$ content increases for cupronickel alloys. Subramanian et al. [3] studied the corrosion behavior of a cupronickel alloy $(70 \mathrm{Cu}-30 \mathrm{Ni})$ in permanganic acid medium and found that uniform corrosion took place in the alloy, but not pitting corrosion. Saifi et al. [4] studied the corrosion inhibition of cupronickel alloy (70Cu-30Ni) in aerated $0.5 \mathrm{M} \mathrm{H}_{2} \mathrm{SO}_{4}$ with cysteine (amino acid) and indicated that the efficiency of corrosion inhibition reached $91 \%$ in inhibitor concentration of $10^{-3} \mathrm{M}$. Al-Fozan et al. [5] reported the sequence of depth of corrosion pits on several alloys immersed in seawater at waterline zone, including three positions, i.e., above seawater level, semi- 
submerged, and fully submerged. The depth of corrosion pits on cupronickel alloy was lower than that of $316 \mathrm{~L} \mathrm{SS}$, but higher than that of Incoloy alloys. According to their study, cupronickel alloys are good material for use in marine environment. For example, the corrosion rate of $70 \mathrm{Cu}-30 \mathrm{Ni}$ cupronickel alloy is $0.015 \mathrm{~mm} /$ per year (mpy) when used in environment above seawater level. In comparison with cupronickel alloy, this value is $0.429,0.027$, and 0.07 , respectively, for carbon steel (G 1010), 304 SS, and 316 SS after similar exposure time. The corrosion rate of cupronickel alloy is lower than that of stainless steels. It is expected that more cupronickel alloys will be used for marine applications. Microbiologically influenced corrosion (MIC) caused by microbial activities is considered to be an important form of corrosion damage for marine installations $[6,7]$. SRB is recognized as one of the main culprits which cause MIC [8-10]. Although research work was done on corrosion of cupronickel alloys in seawater, but the corrosion behavior of cupronickel alloys in corrosive species due to SRB is seldom reported.

In the present work, the corrosion behavior of a cupronickel alloy was studied in simulated seawater in or without the presence of SRB under anaerobic condition. The corrosion behavior of the cupronickel alloy was investigated by electrochemical methods, as well as examination of surface morphologies. For observation of corroded morphologies of metals or alloys induced by SRB, scanning electronic microscopy (SEM) is traditionally used. However, the roughness and pit depth of the corroded metals or alloys could not be reflected only by SEM. In the present work, atomic force microscopy (AFM) and confocal laser scanning microscopy (CLSM) were used to measure the roughness and pit depth of the corroded cupronickel alloy.

\section{Experimental}

\subsection{Materials and Reagents}

A kind of cupronickel alloy was used, and the chemical composition (wt\%) is as follows: $0.03 \mathrm{~S}, 0.03 \mathrm{P}, 0.30 \mathrm{C}$, $1.20 \mathrm{Si}, 1.50 \mathrm{Mn}, 3.50 \mathrm{Fe}, 28.00 \mathrm{Cu}$ and $\mathrm{Ni}$ balanced. All the chemicals were analytic grade. The following chemicals were used, including $\mathrm{NH}_{4} \mathrm{Cl}, \mathrm{MgSO}_{4} \cdot 7 \mathrm{H}_{2} \mathrm{O}, \mathrm{CaCl}_{2}$ $6 \mathrm{H}_{2} \mathrm{O}$, sodium citrate, sodium lactate, $\left(\mathrm{NH}_{4}\right)_{2} \mathrm{Fe}\left(\mathrm{SO}_{4}\right)_{2}$, $\mathrm{KH}_{2} \mathrm{PO}_{4}$, yeast extract, and anhydrous ethanol.

\subsection{Preparation of Samples}

Two types of samples were prepared. One type of samples with dimension of $10 \mathrm{~mm} \times 10 \mathrm{~mm} \times 4 \mathrm{~mm}$ was cut from the as-received cupronickel alloy sheet for immersion tests. Prior to the immersion tests, the samples were washed ultrasonically in acetone for degreasing and then successively abraded with 240, 400, 800, 1000, and 2000 grits emery paper. After being polished with $1.5 \mu \mathrm{m}$ diamond paste, the samples were washed in distilled water and then ethanol for dehydration. The others for electrochemical tests are the same as for the immersion tests. The electrodes for electrochemical measurements were prepared by welding a $\mathrm{Cu}$ wire connected to the backside of the samples. The samples were embedded in mold of epoxy resin mixed with polyamide hardener (3:1 by weight), with exposed area of $10 \mathrm{~mm} \times 10 \mathrm{~mm}$. Prior to the electrochemical tests, the electrode surface was incrementally abraded with SiC emery paper from 240 to 2000 grits, cleaned with ethanol, and then dried with cool air, ready for use.

\subsection{Culture of SRB}

The modified Postgate's C seawater (PCS) was prepared by mixing the following chemicals and solutions together, i.e., $0.50 \mathrm{~g}$ of $\mathrm{KH}_{2} \mathrm{PO}_{4}, 1.00 \mathrm{~g}$ of $\mathrm{NH}_{4} \mathrm{Cl}, 0.06 \mathrm{~g}$ of $\mathrm{CaCl}_{2} \cdot 6 \mathrm{H}_{2} \mathrm{O}$, $0.06 \mathrm{~g}$ of $\mathrm{MgSO}_{4} \cdot 7 \mathrm{H}_{2} \mathrm{O}, 0.30 \mathrm{~g}$ of sodium citrate, $1.00 \mathrm{~g}$ of yeast extract, $6 \mathrm{~mL}$ of $70 \%$ sodium lactate in $1 \mathrm{~L} 3.5 \%$ simulated seawater. The modified PCS was sealed in sterilized glass bottles and aerated using $\mathrm{N}_{2}$ to eliminate oxygen for $20 \mathrm{~min}$. Then, the culture medium was autoclaved at $121^{\circ} \mathrm{C}$ for $20 \mathrm{~min}$. The starting SRB strains were sulfatereducing bacteria (SRB) Desulfovibrio caledoniensis.

The SRB culture and $0.06 \mathrm{~g}$ of $\left(\mathrm{NH}_{4}\right)_{2} \mathrm{Fe}\left(\mathrm{SO}_{4}\right)_{2}$ were injected into the cooled modified PCS as mentioned above and incubated in sterilized glass bottles aerated using $\mathrm{N}_{2}$ for $20 \mathrm{~min}$ in a room-temperature incubator for 3 or 4 days. The corrosive medium with SRB was prepared as follows: $5 \mathrm{vol} \%$ of SRB strains was inoculated into $1 \mathrm{~L}$ of $3.5 \%$ simulated seawater in glass bottles aerated using $\mathrm{N}_{2}$. Then, the glass bottles were covered with rubber plugs and sealed with silicone rubber, aiming to prevent the solution from contacting with air.

\subsection{Immersion Tests}

The solution for test was prepared by injecting $50 \mathrm{~mL}$ of culture medium or $50 \mathrm{~mL}$ of SRB seed bacteria into $1 \mathrm{~L}$ of $3.5 \%$ simulated seawater. The former solution was for the control simulated seawater, and the latter for the simulated seawater with SRB. The samples were immersed in the solutions for 15 days at room temperature. After immersion with and without SRB, all the samples of cupronickel alloy were rinsed with phosphate buffer solutions (PBS) (containing $\mathrm{KH}_{2} \mathrm{PO}_{4}$ of $27.00 \mathrm{~g} / \mathrm{L}, \mathrm{Na}_{2} \mathrm{HPO}_{4}$ of $1.42 \mathrm{~g} / \mathrm{L}$, $\mathrm{NaCl}$ of $8.00 \mathrm{~g} / \mathrm{L}$, and $\mathrm{KCl}$ of $0.20 \mathrm{~g} / \mathrm{L}$ ).

The samples immersed in the simulated seawater with SRB were fixed in 5\% glutaraldehyde for $2 \mathrm{~h}$ and then washed with PBS and distilled water. Then, the samples 
were immersed in ethanol for $30 \mathrm{~min}$ for dehydration. The samples of cupronickel alloy immersed in the simulated seawater without SRB were washed with distilled water and then immersed in ethanol for $30 \mathrm{~min}$ for dehydration. Finally, all the samples with corrosion products were dried with cool air. Also, the samples were sputtered with gold to allow morphological observation by SEM.

The above samples were ultrasonically cleaned in derusting agent (containing $150 \mathrm{~mL}$ of hydrochloric acid and $850 \mathrm{~mL}$ of distilled water) to remove corrosion products on the samples. Then, the samples were washed with distilled water and ethanol. Finally, the samples without corrosion products were dried with cool air and sputtered with gold to allow morphological analysis with SEM.

\subsection{Morphological Observation and Analysis}

The surface morphologies of the samples before and after immersion were observed by SEM. The elements were analyzed by energy dispersive spectroscopy (EDS). The surface roughness of the samples was detected by atomic force microscopy. The morphologies and pit depth of the samples after removal of corrosion products were examined by confocal laser scanning microscope (CLSM, OLS 400).

\subsection{Electrochemical Measurements}

Electrochemical impedance spectra (EIS) were performed using an EG\&G Parstat 2273. All electrochemical tests were performed in a three-electrode cell consisting of a saturated calomel electrode (SCE), a platinum foil electrode, and a sample used as reference, counter, and working electrode, respectively. The measurements were taken in anaerobic $3.5 \%$ simulated seawater with and without SRB. The EIS spectra were acquired in a frequency range from $100 \mathrm{kHz}$ to $10 \mathrm{mHz}$ using an AC signal amplitude of $10 \mathrm{mV}$. The EIS data were fitted and analyzed using Zsimpwin software. During immersion for 15 days, open circuit potentials of the samples were recorded. For electrochemical measurements, three parallel samples were tested to check the consistency and repeatability of the results.

\section{Results and Discussion}

\subsection{Surface Morphologies Analysis}

\subsubsection{Macro Morphology Analysis}

Figure 1 shows the photos of the cupronickel alloy after exposure in the simulated seawater without and with SRB for 15 days. There are no corrosion products on the surface of the cupronickel alloy after immersion in the simulated seawater without SRB (Fig. 1a). However, black corrosion products can be found on the surface of the cupronickel alloy after exposure in the simulated seawater with SRB (Fig. 1b).

\subsubsection{AFM}

Figure 2a, b shows the typical 3D AFM images of the cupronickel alloy after exposure in the simulated seawater without and with SRB for 15 days, respectively. It can be clearly seen that the surface roughness of the sample with SRB (Fig. 2b) was higher than that of the sample immersed in the simulated seawater without SRB (Fig. 2a). The surface of the sample after exposure in the simulated seawater without SRB for 15 days was relatively flat with bulges. The average roughness of the surface is $38 \mathrm{~nm}$. However, the surface of the sample after exposure in the simulated seawater with SRB for 15 days was uneven with sharp peaks. The average roughness of the surface is $113 \mathrm{~nm}$.

\subsubsection{SEM and EDS Analysis}

Figure 3 shows the SEM images and element distribution of the cupronickel alloy after exposure in the simulated seawater without and with SRB for 15 days. Figure 3a shows that slight corrosion occurred on the sample after 15 days of exposure in the simulated seawater without SRB. Figure $3 b$ shows the presence of SRB strains and corrosion products attached to the sample surface after 15 days of exposure in the simulated seawater with SRB. EDS indicates the enrichment of S on the cupronickel alloy after exposure in the simulated seawater with SRB for 15 days, which could be aroused by corrosion of the alloy due to SRB [11]. This result reveals that sulfide produced on the surface of sample after immersion in the simulated seawater with SRB. The amount of $\mathrm{Ni}(39.7 \mathrm{wt} \%)$ and $\mathrm{Cu}$ (29.7 wt \%) on the surface of the sample after immersion in the simulated seawater with $\mathrm{SRB}$ is lower than that $\mathrm{Ni}$ (52.1 wt $\%)$ and $\mathrm{Cu}(32.3 \mathrm{wt} \%)$ of the sample after immersion in the simulated seawater without SRB, suggesting that part of $\mathrm{Ni}$ and $\mathrm{Cu}$ on the surface has transformed to $\mathrm{NiS}, \mathrm{NiO}, \mathrm{CuS}$, and $\mathrm{CuO}$ [12]. Figure 4 is the higher magnification image of Fig. 3. SRB strains attached to the sample surface can be observed. Moreover, a layer of corrosion products can be also found.

\subsubsection{Confocal Laser Scanning Microscopy (CLSM) Analysis}

Figures 5 and 6 show the optical CLSM images and the typical 3D images after removing corrosion products on the 

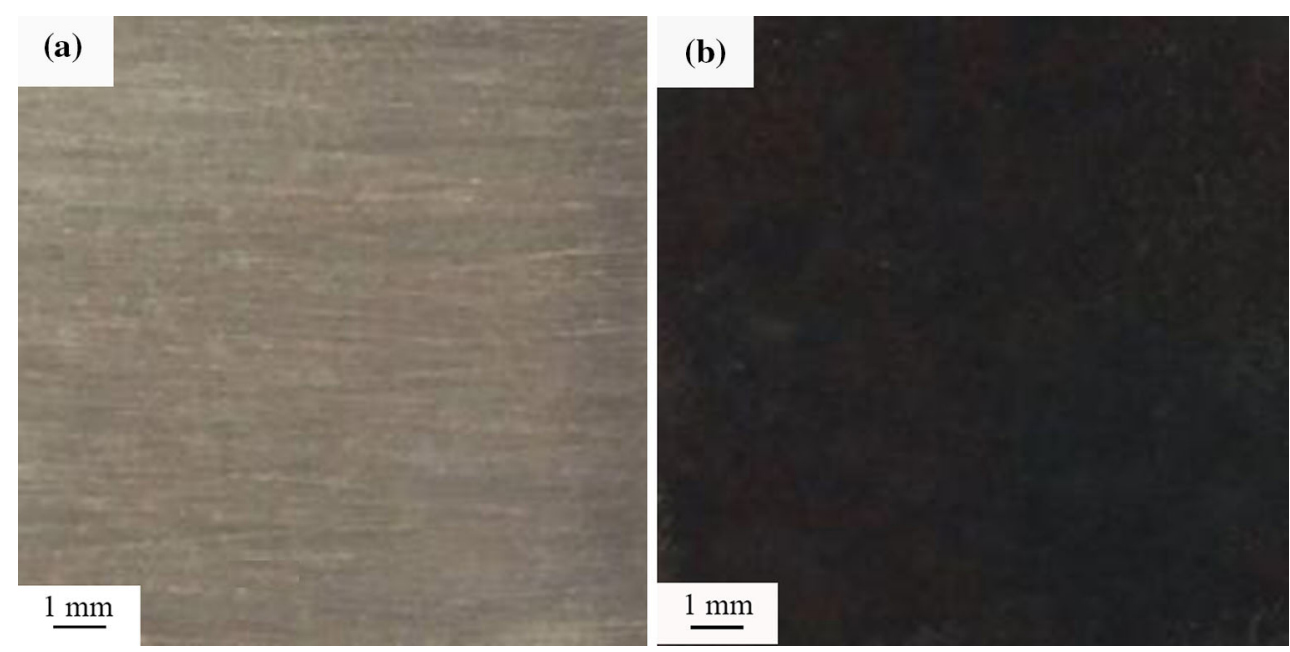

Fig. 1 Photographs of the cupronickel alloy after exposure in the simulated seawater without (a), with (b) SRB for 15 days
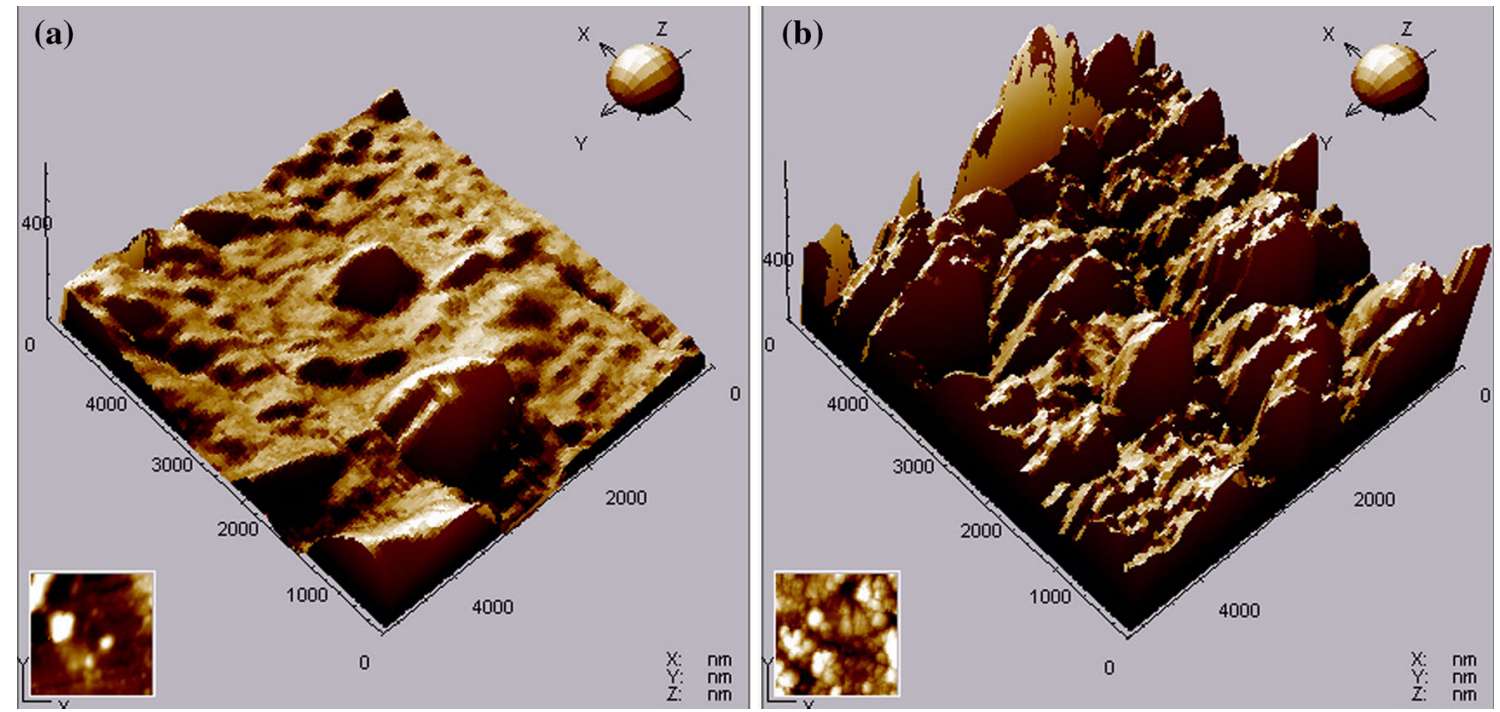

Fig. 2 3D AFM images of the cupronickel alloy after 15 days of exposure in the simulated seawater without (a), with (b) SRB

surface of the cupronickel alloy, respectively. From Figs. 5a and 6a, no obvious corrosion pits were found on the sample after immersion in the simulated seawater without SRB. By contrast, from Figs. $5 \mathrm{~b}$ and $6 \mathrm{~b}$, it can be seen that corrosion pits appeared on the sample after immersion in the simulated seawater with SRB. According to the statistics of average pit depth from CLSM (Table 1), it can be confirmed that SRB accelerated corrosion of the cupronickel alloy. The average pit depth on the sample in simulated seawater with SRB $(16.6 \mu \mathrm{m})$ is much higher than that on the sample in the simulated seawater without SRB $(9.3 \mu \mathrm{m})$.

\subsection{Open Circuit Potential $\left(E_{\text {OCP }}\right)$}

Figure 7 shows the evolution of $E_{\mathrm{OCP}}$ of the cupronickel alloy at different exposure times in the simulated seawater with and without SRB. $E_{\mathrm{OCP}}$ of the sample in the simulated seawater with SRB is lower than that of the sample in the simulated seawater without SRB. In the case of the sample in the simulated seawater without SRB, $E_{\mathrm{OCP}}$ gradually decreases. In the case of the sample in the simulated seawater with $\mathrm{SRB}, E_{\mathrm{OCP}}$ decreases markedly during the first 2 days, which may be a result of the increase of conductivity due to the sulfides [13]. Then, $E_{\mathrm{OCP}}$ shows an increase of $60 \mathrm{mV}$ from 7 to 15 days of immersion, which may be ascribed to the gradual increase of the thickness and compactness of the corrosion products. 

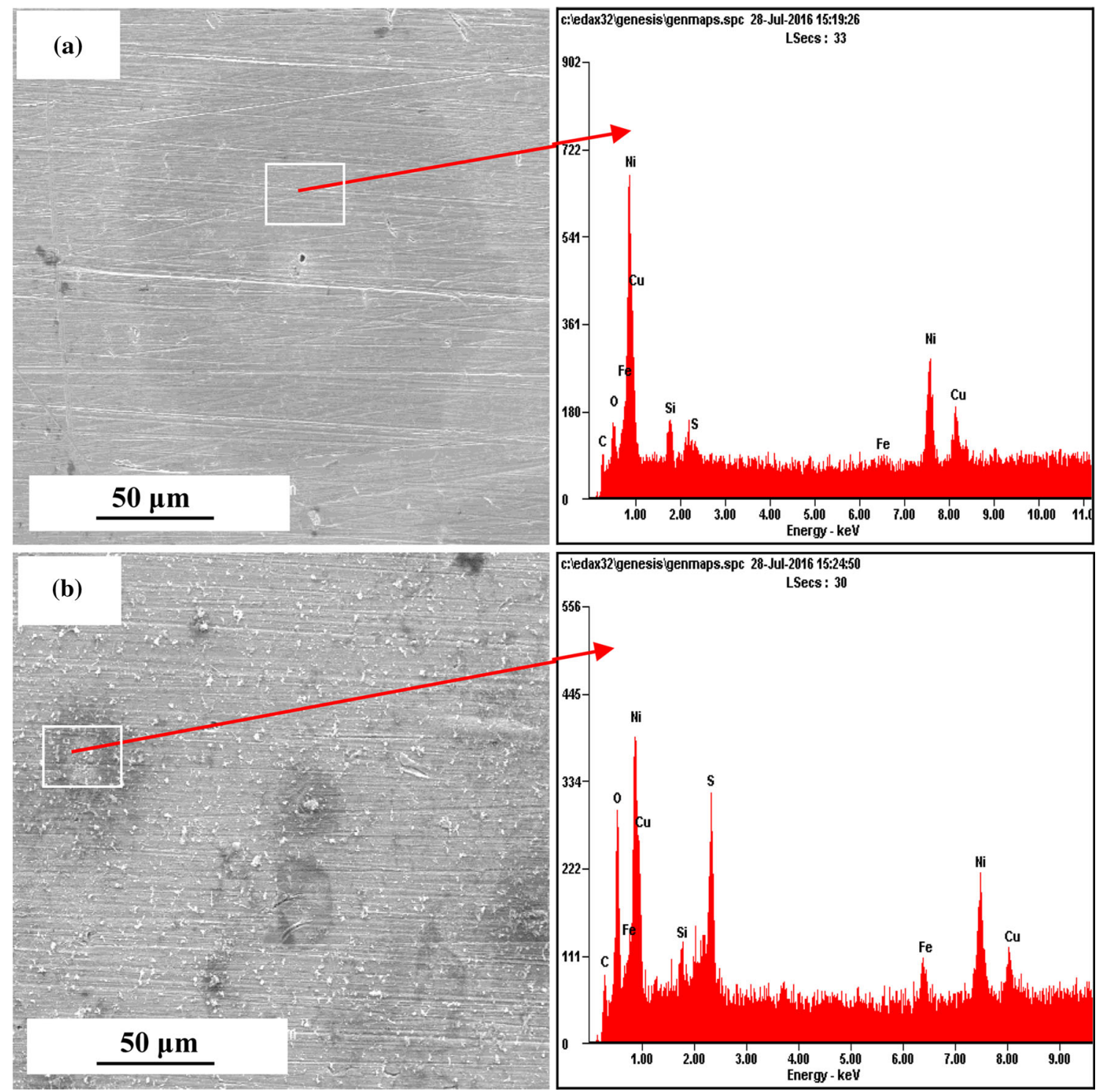

Fig. 3 SEM images and element distribution of the cupronickel alloy after exposure in the simulated seawater without (a), with (b) SRB for 15 days

\subsection{EIS Analysis}

EIS is an effective electrochemical method to evaluate the corrosion behavior of metals or alloys [14-16]. Figures 8a and $b, 9 a$ and $b$ show the EIS spectra of the samples after different times of exposure in the simulated seawater without and with SRB. The impedance values in the low frequency range of the sample immersed in the simulated seawater without SRB are higher than those of the sample immersed in the simulated seawater with SRB. During the initial stage of immersion (1-3 days), the impedance values in the low frequency range of the sample immersed in the simulated seawater without SRB decrease remarkably (Fig. 8a), which may be due to serious corrosion of the alloy [17]. However, the impedance values in low frequency range increase with the elongation of immersion time (7-15 days), which may be due to the formation of corrosion product layer on the sample [18]. The impedance values in the low frequency range of the sample immersed in the simulated seawater with SRB decrease with the increase of immersion time (Fig. 9a). As indicated in Figs. $8 \mathrm{~b}$ and $9 \mathrm{~b}$, the time constants of EIS spectra change from two for the sample in the simulated without SRB to three for the sample in the simulated seawater with SRB. The time constant in the high frequency range may be associated with the formation of biofilm on the sample, and the time constant in the low frequency range may be related to corrosion product layer. The reason of the corrosion acceleration of the cupronickel alloy induced by SRB is that the activity of SRB often causes the formation 


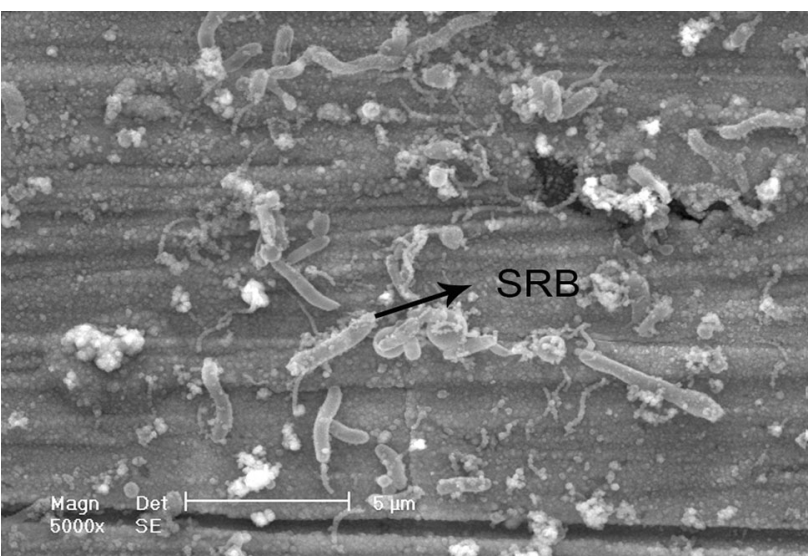

Fig. 4 SEM image of SRB strains on the surface of cupronickel alloy after immersion in the simulated seawater with SRB

of copper sulfide film on the sample surface. The film is porous and has no protective ability for the alloy. The copper sulfide and oxygen accelerate the corrosion of cupronickel alloy [19].

Figure 10 illustrates the electrical equivalent circuits (EEC) used for fitting the impedance spectra of the samples immersed in the simulated seawater without SRB
(Fig. 10a) and with SRB (Fig. 10b). In the EECs, $R_{\mathrm{s}}$ represents the solution resistance, $Q_{\mathrm{bf}}$ represents the capacitance of biofilm, $R_{\mathrm{bf}}$ represents the resistance of biofilm, $Q_{\text {cp }}$ represents the capacitance of corrosion product layer, $R_{\mathrm{cp}}$ represents the resistance of corrosion product layer, $Q_{\mathrm{dl}}$ represents the capacitance of the double layer, and $R_{\mathrm{ct}(1)}$ and $R_{\mathrm{ct}(2)}$ represent the charge transfer resistance without and with SRB, respectively. The EEC containing two time constants, $R(Q(R(Q R)))$, was well used to fit the EIS data of the steel in the simulated seawater without SRB. The EEC containing three time constants, $R(Q(R(Q(R(Q R)))))$, was suitable to fit the EIS data of the steel in the simulated seawater with SRB [20].

Because the capacitance of the biofilm, the corrosion product layer, and the double layer deviates from pure capacitance, a constant phase angle element (CPE), $Q$ is used to replace capacitance $(C)$, which is indicated by the following expression $[21,22]$ :

$Z_{Q_{\mathrm{dl}}}=Y_{0}^{-1}(j \omega)^{-n}$

where $Y_{0}$ denotes the magnitude of $\mathrm{CPE}$, which can be transformed into $Q, \omega$ is the angular frequency, and $n$ is a dispersion coefficient $(0<n \leq 1, n=1$, when CPE is the
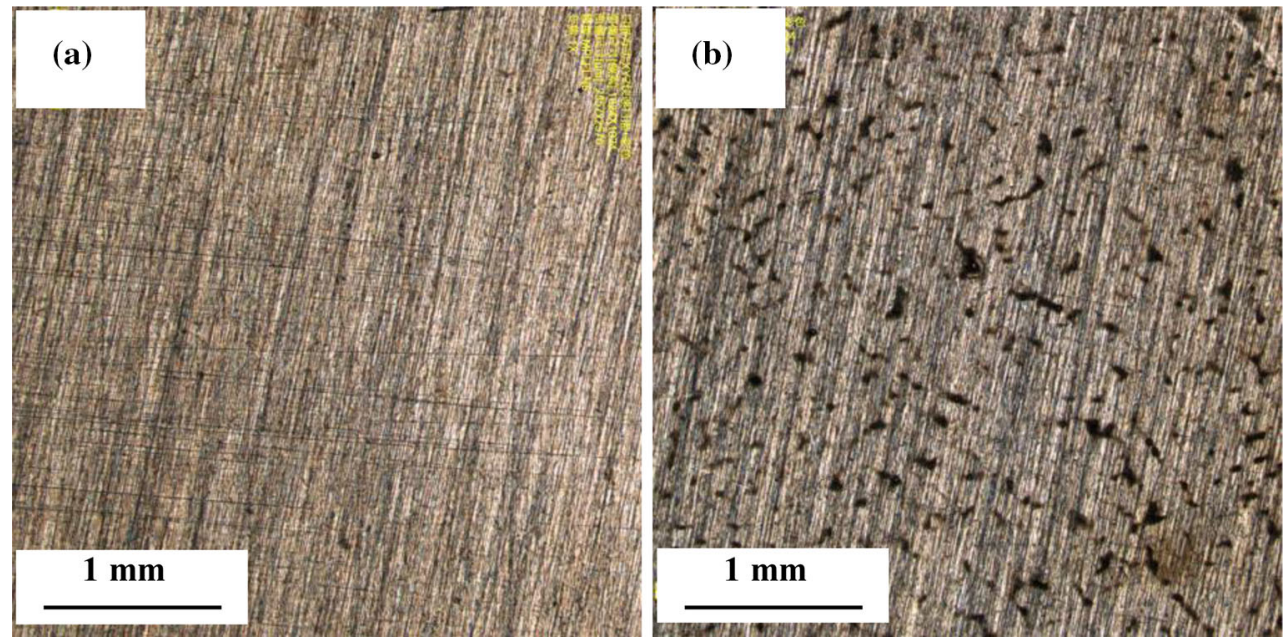

Fig. 5 Optical images of CLSM of the cupronickel alloy after exposure in the simulated seawater without (a), with (b) SRB for 15 days
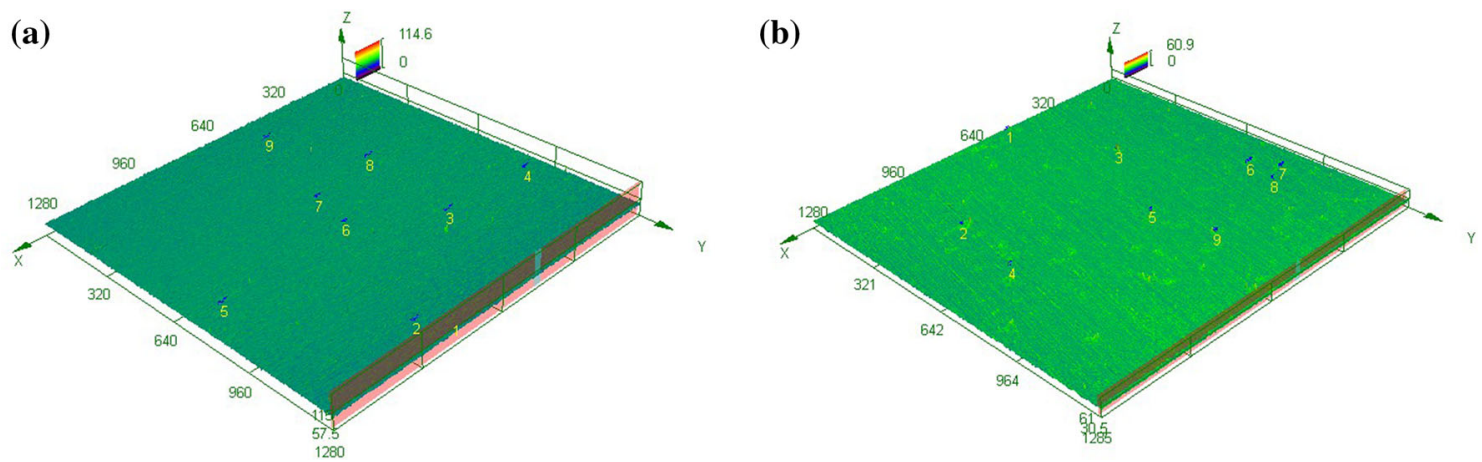

Fig. 6 3D CLSM images of the cupronickel alloy after 15 days of exposure in the simulated seawater without (a), with (b) SRB 
Table 1 Depth of pits of the cupronickel alloy after exposure in the simulated seawater with and without SRB for 15 days

\begin{tabular}{lllrr}
\hline & Time (days) & Maximum $(\mu \mathrm{m})$ & Minimum $(\mu \mathrm{m})$ & Average $(\mu \mathrm{m})$ \\
\hline Without SRB & 15 & 11.1 & 9.4 & 9.3 \\
With SRB & 15 & 27.9 & 13.5 & 16.6 \\
\hline
\end{tabular}

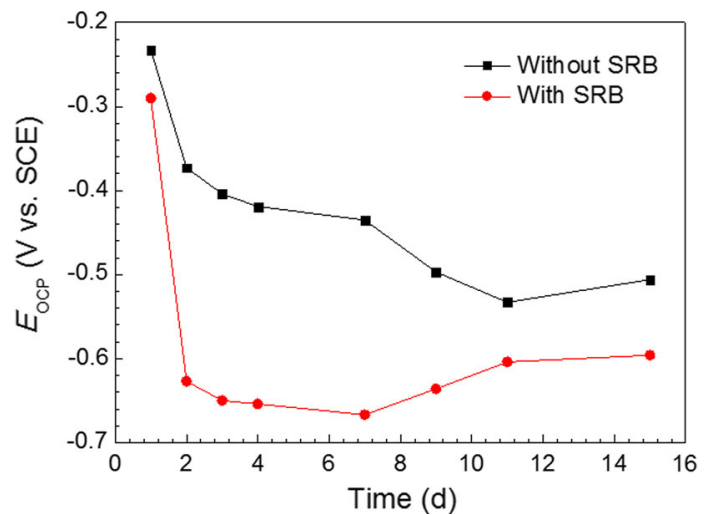

Fig. 7 Evolution of $E_{\mathrm{OCP}}$ with exposure time for the cupronickel alloy immersed in the simulated seawater with and without SRB pure capacitance) that can reflect the intensity of dispersion effect. The fitting results are given in Tables 2 and 3 . In the simulated seawater without SRB, the $R_{\text {cp }}$ in the initial stage of immersion increases, then decreases in the latter stage of immersion (see Table 2). This result may be related to a thin corrosion product layer produced on the alloy surface shortly after immersion. However, the corrosion product layer was dissolved with the increase of immersion time afterward [9, 23]. The $R_{\mathrm{bf}}$ of the sample immersed in the simulated seawater with SRB is relatively high from 1 to 3 days, indicating the fast reproduction of SRB. The subsequent decrease of $\mathrm{R}_{\mathrm{bf}}$ may be ascribed to the destroying of SRB biofilm. The $1 / R_{\mathrm{ct}}$ of the sample immersed in the simulated seawater with $\mathrm{SRB}$ is much bigger than that in
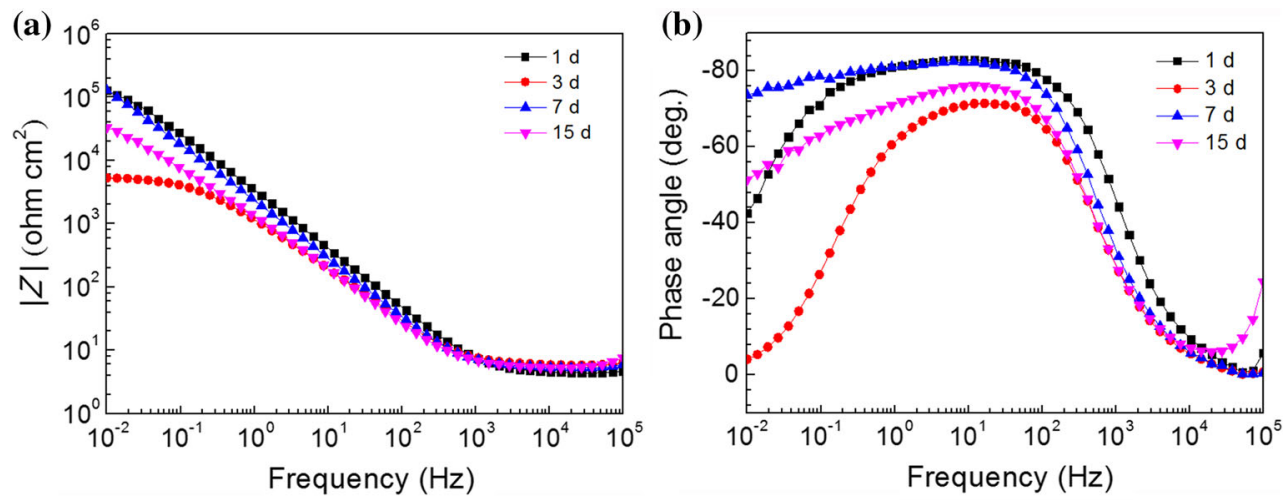

Fig. 8 Bode plots of the EIS spectra of the sample after exposure in the simulated seawater without SRB for different time
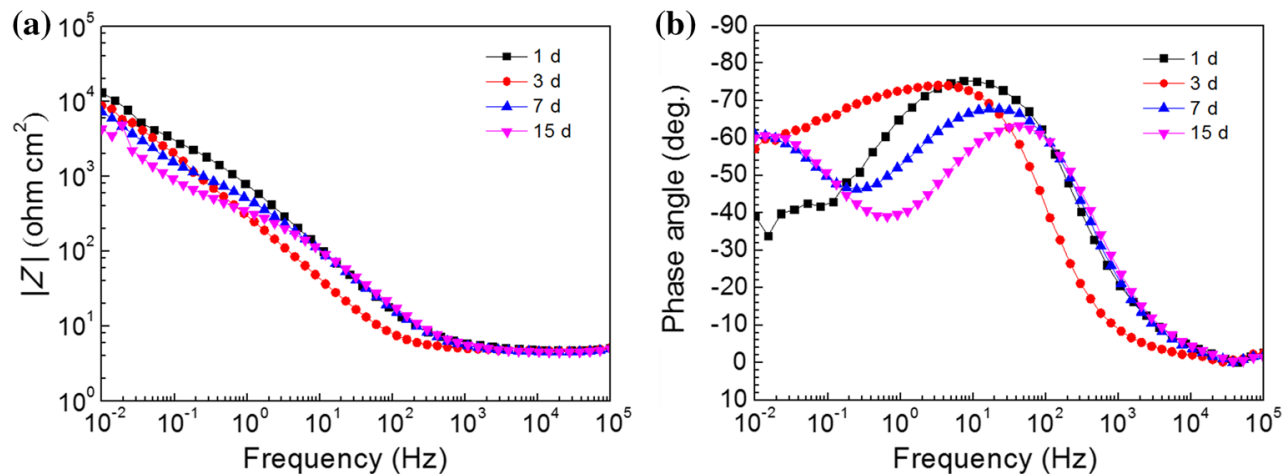

Fig. 9 Bode plots of the EIS spectra of the sample after exposure in the simulated seawater with SRB for different time 

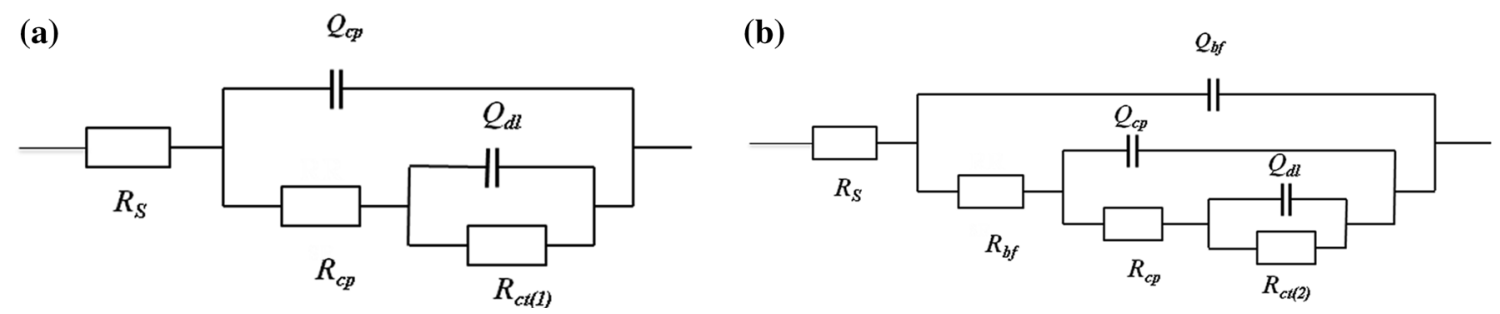

Fig. 10 Electrical equivalent circuits used for fitting the EIS spectra of the sample in the simulated seawater without (a), with (b) SRB

Table 2 Fitted parameters of EIS of the cupronickel alloy after exposure in the simulated seawater without SRB for different time

\begin{tabular}{|c|c|c|c|c|c|c|c|}
\hline Time (days) & $R_{\mathrm{s}}\left(\Omega \mathrm{cm}^{2}\right)$ & $R_{\mathrm{cp}}\left(\Omega \mathrm{cm}^{2}\right)$ & $Q_{\mathrm{cp}}\left(\mathrm{S} \mathrm{cm}^{-2} \mathrm{~s}^{\mathrm{n}}\right)$ & $n_{\mathrm{f}}$ & $R_{\mathrm{ct}(1)}\left(\Omega \mathrm{cm}^{2}\right)$ & $C_{\mathrm{dl}}\left(\mathrm{S} \mathrm{cm}^{-2} \mathrm{~s}^{\mathrm{n}}\right)$ & $n_{\mathrm{dl}}$ \\
\hline 1 & 5.863 & $2.123 \times 10^{3}$ & $1.429 \times 10^{-4}$ & 0.86 & $3.220 \times 10^{3}$ & $9.120 \times 10^{-5}$ & 0.77 \\
\hline 3 & 4.483 & $3.191 \times 10^{4}$ & $5.198 \times 10^{-5}$ & 0.93 & $2.133 \times 10^{5}$ & $1.148 \times 10^{-5}$ & 0.52 \\
\hline 7 & 5.451 & $4.014 \times 10^{4}$ & $7.584 \times 10^{-5}$ & 0.93 & $2.228 \times 10^{6}$ & $1.300 \times 10^{-5}$ & 0.66 \\
\hline 15 & 5.729 & $2.082 \times 10^{3}$ & $1.217 \times 10^{-4}$ & 0.90 & $2.016 \times 10^{5}$ & $8.148 \times 10^{-5}$ & 0.54 \\
\hline
\end{tabular}

Table 3 Fitted parameters of EIS of the cupronickel alloy after exposure in the simulated seawater with SRB for different time

\begin{tabular}{lllllllllll}
\hline $\begin{array}{l}\text { Time } \\
\text { (days) }\end{array}$ & $\begin{array}{l}R_{\mathrm{s}} \\
\left(\Omega \mathrm{cm}^{2}\right)\end{array}$ & $\begin{array}{l}R_{\mathrm{bf}} \\
\left(\Omega \mathrm{cm}^{2}\right)\end{array}$ & $\begin{array}{l}Q_{\mathrm{bf}} \\
\left(\mathrm{S} \mathrm{cm}^{-2} \mathrm{~s}^{\mathrm{n}}\right)\end{array}$ & $n_{\mathrm{f}}$ & $R_{\mathrm{cp}}\left(\Omega \mathrm{cm}^{2}\right)$ & $\begin{array}{l}Q_{\mathrm{cp}} \\
\left(\mathrm{S} \mathrm{cm}^{-2} \mathrm{~s}^{\mathrm{n}}\right)\end{array}$ & $n_{\mathrm{f}}$ & $\begin{array}{l}R_{\mathrm{ct}(2)} \\
\left(\Omega \mathrm{cm}^{2}\right)\end{array}$ & $\begin{array}{l}C_{\mathrm{dl}} \\
\left(\mathrm{S} \mathrm{cm}^{-2} \mathrm{~s}^{\mathrm{n}}\right)\end{array}$ & $\begin{array}{l}n_{\mathrm{dl}} \\
1\end{array}$ \\
\hline 4.897 & 69.04 & $2.418 \times 10^{-4}$ & 0.87 & $1.282 \times 10^{4}$ & $8.554 \times 10^{-4}$ & 0.97 & $4.132 \times 10^{3}$ & $6.567 \times 10^{-6}$ & 0.69 \\
3 & 4.758 & 2.409 & $6.283 \times 10^{-4}$ & 0.88 & $5.447 \times 10^{3}$ & $2.091 \times 10^{-4}$ & 0.96 & $2.709 \times 10^{4}$ & $1.425 \times 10^{-3}$ & 0.97 \\
7 & 4.589 & 2.812 & $5.788 \times 10^{-5}$ & 1.00 & $3.641 \times 10^{4}$ & $1.313 \times 10^{-3}$ & 0.83 & $8.461 \times 10^{2}$ & $4.004 \times 10^{-4}$ & 0.71 \\
15 & 4.572 & 2.402 & $4.955 \times 10^{-5}$ & 1.00 & $3.760 \times 10^{4}$ & $1.967 \times 10^{-3}$ & 0.78 & $3.530 \times 10^{2}$ & $4.096 \times 10^{-4}$ & 0.68 \\
\hline
\end{tabular}

the simulated seawater without SRB. Especially, $1 / R_{\mathrm{ct}}$ of the sample immersed in the simulated seawater with SRB is one or two orders of magnitude higher than that of the sample immersed in the simulated seawater without SRB on the 7 th and 15 th day.

\section{Conclusions}

The corrosion behavior of cupronickel alloy in the simulated seawater in and without the presence of SRB under anaerobic condition was studied. SEM observation shows much serious corrosion occurred on the alloy sample immersed in the simulated seawater with SRB than on the alloy sample immersed in the simulated seawater without SRB. The AFM and CLSM images present the rough surface of the alloy after immersion in the simulated seawater with SRB, and corrosion pits are apparent. The increase of time constants of EIS spectra indicates the acceleration of corrosion rate of the alloy when the alloy sample was immersed in the simulated seawater with SRB.

Acknowledgements The authors would like to thank the financial support from National Basic Research Program of China (No.
2014CB643304), the Key Technology of Corrosion Control on Wind Power Equipment Academician Workstation Project (No. 2013B090400023), and the National Natural Science Foundation of China (Grant No. 51571202).

\section{References}

[1] G.J. Abraham, V. Kain, G.K. Dey, Eng. Fail. Anal. 16, 934 (2009)

[2] W.A. Badawy, K.M. Ismail, A.M. Fathi, J. Alloys Compd. 484, 365 (2009)

[3] V. Subramanian, P. Chandramohan, M.P. Srinivasan, S. Velmurugan, S.V. Narasimhan, Corros. Sci. 49, 620 (2007)

[4] H. Saifi, M.C. Bernard, S. Joiret, K. Rahmouni, H. Takenouti, B. Talhi, Mater. Chem. Phys. 120, 661 (2010)

[5] Saleh A. Al-Fozan, Anees U. Malik, Desalination 228, 61 (2008)

[6] C. Xu, Y. Zhang, G. Cheng, Mater. Charact. 59, 245 (2008)

[7] D.K. Xu, Y.C. Li, F.M. Song, T.Y. Gu, Corros. Sci. 77, 385 (2013)

[8] M. Moradi, J. Duan, H. Ashassi-Sorkhabi, X. Luan, Corros. Sci. 53, $4282(2011)$

[9] T.Q. Wu, J. Xu, M.C. Yan, C. Sun, C.K. Yu, W. Ke, Corros. Sci. 83, 38 (2014)

[10] T.Q. Wu, M.C. Yan, D.C. Zeng, J. Xu, C.K. Yu, C. Sun, W. Ke, Acta Metall. Sin. (Engl. Lett.) 28, 93 (2015)

[11] J. Li, J.Y. Li, W.S. Yuan, Y.L. Du, Int. Biodeterior. Biodegrad. 64, 363 (2010) 
[12] Kristen M. Kruszewski, Emilee R. Renk, Ellen S. Gawalt, Thin Solid Films 520, 4326 (2012)

[13] J. Cai, K.S. Wang, C.P. Miao, W.B. Li, W. Wang, J. Yang, Mater. Des. 65, 272 (2015)

[14] Q.H. Zhao, W. Liu, Y.C. Zhu, B.L. Zhang, S.Z. Li, M.X. Lu, Acta Metall. Sin. (Engl. Lett.) 30, 164 (2017)

[15] C. Thee, L. Hao, J.H. Dong, X. Mu, W. Ke, Acta Metall. Sin. (Engl. Lett.) 28, 261 (2015)

[16] L.Y. Zheng, F.H. Cao, W.J. Liu, B.L. Jia, J.Q. Zhang, Acta Metall. Sin. (Engl. Lett.) 23, 416 (2010)

[17] C. Hao, R.H. Yin, Z.Y. Wan, Q.J. Xu, G.D. Zhou, Corros. Sci. 50, 3527 (2008)
[18] J. Zhang, Q. Wang, Y.M. Wang, L.S. Wen, C. Dong, J. Alloys Compd. 505, 179 (2010)

[19] J.S. Patil, A.C. Anil, Int. Biodeterior. Biodegrad. 105, 203 (2015)

[20] L.L. Campbell, J.R. Postgate, Bact. Rev. 29, 359 (1965)

[21] Robert E. Melchers, Corros. Sci. 81, 110 (2014)

[22] F. Li, M. An, G. Liu, D. Duan, Mater. Chem. Phys. 113, 971 (2009)

[23] G. Regurea, K.P. Nevin, J.S. Nicoll, Appl. Environ. Microbiol. 72, 7348 (2006) 